\title{
Effects of Sunset Yellow FCF on immune system organs during different chicken embryonic periods
}

\author{
Fatma Çolakoğlu ${ }^{1 凶}$, Muhammet Lütfi Selçuk ${ }^{2}$ \\ ${ }^{1}$ Department of Nutrition and Dietetics, ${ }^{2}$ Department of Physiotherapy and Rehabilitation, \\ Faculty of Health Sciences, Karamanoğlu Mehmetbey University, 70200 Karaman, Turkey \\ fcolakoglu@kmu.edu.tr
}

Received: March 25, $2020 \quad$ Accepted: September 25, 2020

\begin{abstract}
Introduction: Sunset Yellow FCF (SY), used frequently in ready-made foods, cosmetics, and the pharmaceutical industry, may cause many health problems. This study is intended to evaluate the morphological and cellular effects of SY on the embryonic chicken immune system throughout incubation. Material and Methods: Babcock white leghorn eggs were randomly divided into four groups. Besides a control group, there were three treatment groups which received a single injection of 200, 1,000, or 2,000 ng of SY into the air sac just before incubation. The eggs were opened on the $10^{\text {th }}, 13^{\text {th }}, 16^{\text {th }}$, and $21^{\text {st }}$ days of incubation. Samples of the bursa of Fabricius, thymus, and spleen were taken from embryos. Serial sections of $5 \mu \mathrm{m}$ thickness were stained with histological methods and routine histological procedures were performed. Results: An increase in the spleen volume was determined as the hatching time of the chicks approached. The highest eosinophil ratio was found in the $\mathrm{SY}_{1,000}$ and $\mathrm{SY}_{2,000}$ groups $(\mathrm{P}<0.05)$, where the most significant change was developmental retardation in the thymus. In the bursa of Fabricius, there was less lymphocyte accumulation and eosinophilic cell infiltration with increasing doses. Conclusion: It was concluded that in ovo administered SY has undesired effects on embryonic development of the bursa of Fabricius, spleen, and thymus, and on spleen volume.
\end{abstract}

Keywords: chicken embryonic immune system, bursa of Fabricius, spleen, thymus, Sunset Yellow FCF.

\section{Introduction}

As food dyes increase the attractiveness of food, they are an important group among food additives. These food additives are said not to have significant side effects unless the specified limits are exceeded. A study conducted on synthetic food dyes reported that the permissible rates were exceeded in the majority of the samples and that one of the most widely used food azo dyes was Sunset Yellow FCF (E110) (5). This dye (SY) is a synthetic chemical containing azo groups and is used in many manufacturing processes such as those in the food, drug, cosmetic, textile, and leather industries (13). In 2011, the acceptable daily intake (ADI) was set at 0-2 mg/kg b.w. by the FAO/WHO Joint Expert Committee on Food Additives (JECFA) (24). The European Food Safety Authority (EFSA) also reported that the ADI of SY should be between 1 and $2.5 \mathrm{mg} / \mathrm{kg} \mathrm{b.w./day} \mathrm{(12).}$ Over-exposure to azo dyes may cause serious health problems such as hyperactivity in children, chromosomal aberrations, and allergic reactions (41).
The most important immune or lymphoid organs of poultry are the thymus, bursa of Fabricius, and spleen. These organs form the defence mechanism of the body. The generation, differentiation and maturation of $\mathrm{T}$ and B lymphocytes that are responsible for cellular and humoral immunity take place in the thymus and bursa of Fabricius, respectively. These immunocompetent cells are mostly located in these lymphoid organs. The spleen, as the largest peripheral lymphoid organ, has a role in the interaction of lymphoid and non-lymphoid cells throughout the incubation period of poultry. In other words, the spleen is the immune response production centre $(1,48)$.

In the literature, there is not enough information about the passage and passage rates through the placental barrier of SY in mammals. Chicken eggs without the placental barrier are accepted as the most suitable and preferred material in embryonic and teratogenic studies. A standard method for such studies known as the chicken embryotoxicity screening test (CHEST) was developed by Jelinek et al. (22). The 
obtained results from this test can also be adapted to mammals. CHEST was used in this study, which aims to evaluate the developmental and morpho-histological effects of SY on the thymus, bursa of Fabricius, and spleen. In addition, since the present study is an embryo study, it may provide information about the effects of SY throughout pregnancy.

\section{Material and Methods}

Eggs, embryos, and treatment groups. In this study, 160 Babcock white leghorn eggs were purchased. These initially visibly clean eggs were disinfected. Furthermore, disinfection by formalin fumigation was also performed for the incubator. For this process, a mixture of $40 \mathrm{~mL}$ of formalin $(40 \%)$ and $20 \mathrm{~g}$ potassium permanganate per square metre was used and this mixture disinfected the incubator for $30 \mathrm{~min}$ (37). The disinfected eggs were divided into control, $\mathrm{SY}_{200}$, $\mathrm{SY}_{1,000}$, and $\mathrm{SY}_{2,000}$ groups, numbered and incubated in a hatching machine. Then, the eggs were opened on the $10^{\text {th }}, 13^{\text {th }}, 16^{\text {th }}$, and $21^{\text {st }}$ days of incubation, considering the period of organogenesis. Since we thought that some hatching eggs might be infertile, 10 eggs were allocated to each group. On the appointed days, eggs were opened from each of these groups until six live embryos were obtained.

SY dosing and incubation. The application doses of SY were calculated based on the limit determined by JECFA of $2 \mathrm{mg} / \mathrm{kg}$ b.w. (LD ${ }_{50}$ dose) as the ADI (24). After they were wiped at the blunt end with $96 \%$ ethyl alcohol, the eggs were treated in the air sac with a single injection of 200, 1,000, or 2,000 ng SY (CAS 2783-94-0; $90 \%$ purity, Sigma-Aldrich, Germany) dissolved in $20 \mu \mathrm{L}$ of bi-distilled water. For adaptation of the dilution concentration of the toxic dose that was determined by CHEST is multiplied by $10^{-2}$. The obtained value was considered as the toxic dose per kilogram of maternal body weight in pregnant mammals. In this study, SY doses were calculated with consideration of this multiplier. After they were wiped at the blunt end with $96 \%$ ethyl alcohol, the eggs were treated in the air sac with a single injection of 200, 1,000, and 2,000 ng SY dissolved in $20 \mu \mathrm{L}$ of bi-distilled water. The holes were made with an egg-piercing tool and immediately sealed with liquid paraffin after the injection. All of the injections were performed with an Eppendorf Research Plus sterile-tipped micropipette (Merck, Germany). Incubation followed for 10-21 days in a hatching machine at $37.4-37.6^{\circ} \mathrm{C}$ and $55 \%-65 \%$ humidity.

Collection and processing of tissue samples. On the $10^{\text {th }}, 13^{\text {th }}, 16^{\text {th }}$, and $21^{\text {st }}$ days of incubation, eggs were opened from each of these groups until six live embryos were obtained. The thymus, bursa of Fabricius, and spleen tissue samples were carefully taken from 96 chick embryos and fixed in 10\% neutral-buffered formalin solution. The fixed samples were washed overnight in running water to remove the fixation solution. Then, the samples were dehydrated in a graded alcohol series, cleared in xylene (three times), and embedded in paraffin blocks. Serial sections of $5 \mu \mathrm{m}$ thickness were taken from these tissue blocks at regular intervals using a microtome. Sampling was performed systematically and randomly at the ratio of $1 / 20$ by starting from a random example among the first 10 cross-sections and taking every $20^{\text {th }}$ one. Systematic random sampling ensured that between 8 and 16 cross sections were obtained from spleens. For routine histological examinations and volume calculations, the sections were stained with Crossmon's trichrome stain (46), haematoxylin and eosin (45), and Pappenheim's panoptic stain (29). Additionally, peripheral blood samples were taken via the vitelline veins from the chick embryos on the $13^{\text {th }}, 16^{\text {th }}$, and $21^{\text {st }}$ days of the incubation. Two blood smears were prepared from each sample and air dried. Then, the smears were fixed in a gluteraldehyde-acetone solution at $-10^{\circ} \mathrm{C}$ for $3 \mathrm{~min}$. After fixation, these smears were rinsed three times in distilled water. Then, all smears were allowed to dry at room temperature $\left(20^{\circ} \mathrm{C}\right)$ for $30 \mathrm{~min}$ and stained with May-Grünwald-Giemsa stain to determine the leukocyte formula of the samples (29). All histological preparations were examined with a Leica DM-2500 light microscope attached to a DFC-320 digital camera (Leica, Germany).

Evaluation of the stained tissue samples. In the evaluation of the blood smears, granulocyte production in poultry starts on the $10^{\text {th }}$ day of incubation and its development continues throughout incubation. Therefore, leukocyte separation could not be made on the $13^{\text {th }}$ and $16^{\text {th }}$ days. The leukocyte ratio (\%) was determined in smears on the $21^{\text {st }}$ day of incubation. All leukocytes have nuclei, which distinguish them from other blood cells. According to the varying shapes of nuclei and the presence of granules in their cytoplasm, the peripheral blood smears were cell counted per 100 leukocytes in a light microscope and the formula leukocyte ratios $(\%)$ were calculated. In the present study, the thymus sections were examined using a light microscope for their general histological structure. In the evaluation of the bursa of Fabricius, the average thicknesses of the follicle-related epithelium (FAE) and interfollicular epithelium (IFE) of sections were measured with the ImageJ Analysis Programme (43) from six different areas of epithelia. The spleens were separately weighed using a precision balance and the weights noted. In the histological examination of spleen sections, the average capsule thickness was obtained by measuring six different regions with the analysis programme (9). Spleen volumes were calculated using a point area measurement scale $(\mathrm{d}=0.2 \mathrm{~mm})$ on the cross-sectional images taken at $4 \times$ lens magnification and Cavalieri's principle was applied as the calculation method (Fig. 1). The volumes of the structures of interest in the sections were calculated using the formula $\mathrm{V}=(\mathrm{a} / \mathrm{p}) \times \sum \mathrm{P} \times \mathrm{t}(33)$, where $\mathrm{V}=$ the volume of the structure of the sample of interest, $a / p=$ the area of 
a point in the point area measuring scale, $\sum \mathrm{P}=$ the total number of points on the structure of interest, and $t=$ the average cross-sectional thickness (42). Several methods may be used for coefficient of error (CE) calculation in stereological research. In this study, the CE formula of Gundersen et al. (17) was used.

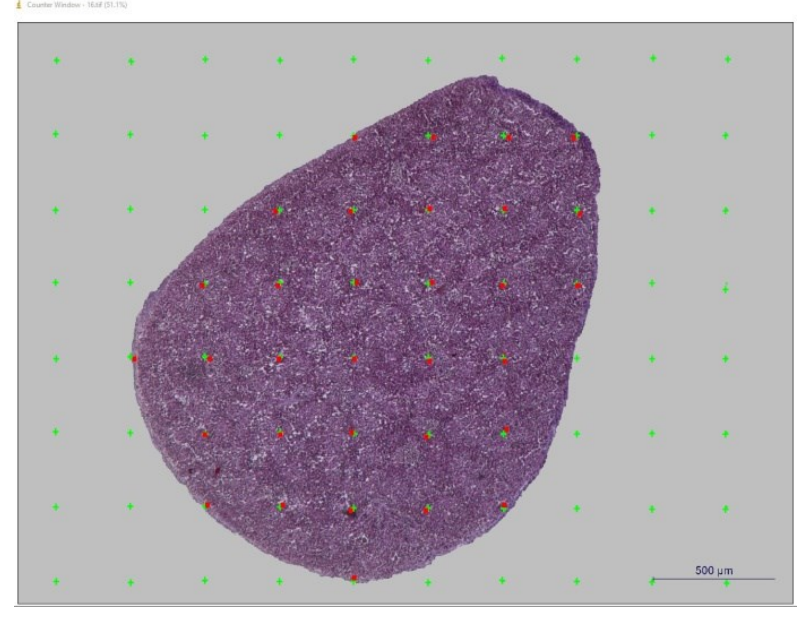

Fig. 1. Application of point counting grid on histological sections of the spleen

Statistical analysis. Statistical analyses were performed using the SPSS software version 21 (IBM SPSS, USA). The variables were investigated using visual and analytical methods (histograms and probability plots and Kolmogorov-Smirnov/ShapiroWilk tests, respectively) to determine whether they are normally distributed. One-way ANOVA was used to compare data obtained from the study and Levene's test was used to assess the homogeneity of the variances. $\mathrm{P}<0.05$ was accepted as statistically significant. When an overall significance was observed, pairwise post-hoc tests were performed using Tukey's method. Data are expressed \pm as means standard error.

\section{Results}

Anatomical changes. The spleen weights and volumes obtained using Cavalieri's method are given for each incubation period in Table 1. Statistically, there was no difference in spleen weights after 10 days of incubation. However, the spleen weights of the SY groups were lower than those of the control group on later days $(\mathrm{P}<0.05)$. An increase in the spleen volume was determined as the hatching time of the chicks approached in Table 1. Generally, there was a significant statistical difference between the control group's and $\mathrm{SY}_{1,000}$ and $\mathrm{SY}_{2,000}$ groups' spleen volumes $(\mathrm{P}<0.001)$ whereas that of the $\mathrm{SY}_{200}$ group was similar both to the control group's and other SY groups' $(\mathrm{P}>0.001)$ on the $21^{\text {st }}$ day of incubation.

Histopathological changes. The proportions of peripheral blood leukocytes on the days of incubation when embryos were sampled are given in Table 2 . In the microscopic evaluation of peripheral blood smears, lymphocyte counts were higher than those of other leukocytes in all groups on the $13^{\text {th }}$ day of incubation. However, heterophile and eosinophil granulocytes were also seen in the $\mathrm{SY}_{1,000}$ and $\mathrm{SY}_{2,000}$ groups. On the $16^{\text {th }}$ day, heterophile granulocytes were more common in the control and $\mathrm{SY}_{200}$ groups, whereas eosinophil granulocytes were more dominant in the $S Y_{1,000}$ and $\mathrm{SY}_{2,000}$ groups. On the $13^{\text {th }}$ and $16^{\text {th }}$ days of incubation, erythrocytes were present at different stages of development. The highest heterophil granulocyte ratios on the $21^{\text {st }}$ day of incubation were in the control and $\mathrm{SY}_{200}$ groups at $58.83 \%$ and $54.00 \%$, respectively $(\mathrm{P}<0.05)$. The highest eosinophil ratio was found in the $\mathrm{SY}_{1,000}$ and $\mathrm{SY}_{2,000}$ groups, whereas the lowest lymphocyte ratio was observed in the $\mathrm{SY}_{2,000}$ group (Fig. 2).

Table 1. Measurement data of structures in the spleen and bursa of Fabricius according to days of incubation (mean \pm SE)

\begin{tabular}{|c|c|c|c|c|c|c|c|}
\hline $\begin{array}{l}\text { Day of } \\
\text { incubation }\end{array}$ & Group & $\begin{array}{l}\text { Spleen weight } \\
(\mathrm{g})\end{array}$ & $\begin{array}{l}\text { Spleen capsule } \\
\text { thickness } \\
(\mu \mathrm{m})\end{array}$ & $\begin{array}{l}\text { Spleen volume } \\
(\mathrm{mL})\end{array}$ & $\mathrm{CE}$ & $\begin{array}{l}\text { FAE thickness } \\
(\mu \mathrm{m})\end{array}$ & $\begin{array}{l}\text { IFE thickness } \\
(\mu \mathrm{m})\end{array}$ \\
\hline \multirow{4}{*}{$10^{\text {th }}$} & $\mathrm{C}$ & $0.001 \pm 0.0$ & $2.030 \pm 0.112^{\mathrm{b}}$ & $0.452 \pm 0.042$ & 0.044 & $15.540 \pm 1.233^{\mathrm{b}}$ & $17.642 \pm 1.106^{\mathrm{b}}$ \\
\hline & $\mathrm{SY}_{200}$ & $0.001 \pm 0.0$ & $1.694 \pm 0.195^{\mathrm{b}}$ & $0.480 \pm 0.033$ & 0.042 & $11.092 \pm 1.161^{\mathrm{a}}$ & $14.945 \pm 0.424^{\mathrm{ab}}$ \\
\hline & $\mathrm{SY}_{1,000}$ & $0.002 \pm 0.0$ & $0.850 \pm 0.317^{\mathrm{a}}$ & $0.451 \pm 0.027$ & 0.047 & $10.565 \pm 0.366^{\mathrm{a}}$ & $13.882 \pm 1.075^{\mathrm{a}}$ \\
\hline & $\mathrm{SY}_{2,000}$ & $0.002 \pm 0.0$ & $0.834 \pm 0.285^{\mathrm{a}}$ & $0.485 \pm 0.028$ & 0.046 & $9.962 \pm 1.120^{\mathrm{a}}$ & $13.862 \pm 0.878^{\mathrm{a}}$ \\
\hline \multirow{4}{*}{$13^{\text {th }}$} & $\mathrm{C}$ & $0.050 \pm 0.004^{\mathrm{b}}$ & $11.051 \pm 1.897$ & $2.538 \pm 0.305$ & 0.046 & $16.178 \pm 2.113^{b}$ & $20.750 \pm 1.492^{b}$ \\
\hline & $\mathrm{SY}_{200}$ & $0.005 \pm 0.001^{\mathrm{a}}$ & $10.399 \pm 1.070$ & $1.784 \pm 0.147$ & 0.044 & $14.178 \pm 1.662^{\mathrm{ab}}$ & $16.882 \pm 2.436^{\mathrm{ab}}$ \\
\hline & $\mathrm{SY}_{1,000}$ & $0.006 \pm 0.001^{\mathrm{a}}$ & $9.232 \pm 0.884$ & $2.386 \pm 0.172$ & 0.041 & $11.142 \pm 1.281^{\mathrm{a}}$ & $15.392 \pm 1.162^{\mathrm{a}}$ \\
\hline & $\mathrm{SY}_{2,000}$ & $0.005 \pm 0.001^{\mathrm{a}}$ & $7.587 \pm 0.639$ & $2.172 \pm 0.218$ & 0.042 & $10.631 \pm 0.414^{\mathrm{a}}$ & $14.355 \pm 1.099^{\mathrm{a}}$ \\
\hline \multirow{4}{*}{$16^{\text {th }}$} & $\mathrm{C}$ & $0.115 \pm 0.011^{\mathrm{b}}$ & $16.412 \pm 1.154$ & $4.280 \pm 0.392$ & 0.029 & $16.166 \pm 0.777^{b}$ & $17.043 \pm 1.187^{b}$ \\
\hline & $\mathrm{SY}_{200}$ & $0.011 \pm 0.001^{\mathrm{a}}$ & $15.892 \pm 1.759$ & $4.952 \pm 0.589$ & 0.045 & $14.525 \pm 0.997^{\mathrm{ab}}$ & $14.135 \pm 1.305^{\mathrm{ab}}$ \\
\hline & $\mathrm{SY}_{1,000}$ & $0.009 \pm 0.002^{\mathrm{a}}$ & $15.339 \pm 1.247$ & $4.536 \pm 0.578$ & 0.028 & $12.015 \pm 0.879^{\mathrm{a}}$ & $13.562 \pm 0.613^{\mathrm{ab}}$ \\
\hline & $\mathrm{SY}_{2,000}$ & $0.013 \pm 0.001^{\mathrm{a}}$ & $12.424 \pm 0.822$ & $4.473 \pm 0.682$ & 0.031 & $11.508 \pm 0.408^{\mathrm{a}}$ & $12.525 \pm 0.841^{\mathrm{a}}$ \\
\hline \multirow{4}{*}{$21^{\mathrm{st}}$} & $\mathrm{C}$ & $0.089 \pm 0.012^{b}$ & $20.418 \pm 1.413^{b}$ & $6.832 \pm 0.491^{\mathrm{b}}$ & 0.019 & $21.025 \pm 2.488^{b}$ & $22.492 \pm 2.609^{b}$ \\
\hline & $\mathrm{SY}_{200}$ & $0.007 \pm 0.001^{\mathrm{a}}$ & $16.386 \pm 1.028^{\mathrm{ab}}$ & $6.001 \pm 0.378^{\mathrm{ab}}$ & 0.021 & $14.983 \pm 2.056^{\mathrm{ab}}$ & $19.708 \pm 0.857^{\mathrm{ab}}$ \\
\hline & $\mathrm{SY}_{1,000}$ & $0.009 \pm 0.002^{\mathrm{a}}$ & $14.804 \pm 0.807^{\mathrm{a}}$ & $4.576 \pm 0.426^{\mathrm{a}}$ & 0.031 & $14.798 \pm 1.640^{\mathrm{a}}$ & $19.002 \pm 1.641^{\mathrm{ab}}$ \\
\hline & $\mathrm{SY}_{2,000}$ & $0.009 \pm 0.001^{\mathrm{a}}$ & $14.168 \pm 1.367^{\mathrm{a}}$ & $4.676 \pm 0.143^{\mathrm{a}}$ & 0.024 & $12.920 \pm 0.836^{\mathrm{a}}$ & $12.572 \pm 1.197^{\mathrm{a}}$ \\
\hline
\end{tabular}

\footnotetext{
a,b: Values within a column with no common superscripts are significant $(\mathrm{P}<0.05)$
} 
Table 2. The proportions of peripheral blood leukocyte for the sampled days of incubation (\%) \pm SE

\begin{tabular}{|c|c|c|c|c|c|c|}
\hline $\begin{array}{l}\text { Day of } \\
\text { incubation }\end{array}$ & Group & Heterophil & Eosinophil & Lymphocyte & Monocyte & Basophil \\
\hline \multirow{4}{*}{$13^{\text {th }}$} & $\mathrm{C}$ & + & + & +++ & - & - \\
\hline & $\mathrm{SY}_{200}$ & + & + & +++ & - & - \\
\hline & $\mathrm{SY}_{1,000}$ & ++ & ++ & +++ & - & - \\
\hline & $\mathrm{SY}_{2,000}$ & ++ & ++ & +++ & - & - \\
\hline \multirow{4}{*}{$16^{\text {th }}$} & $\mathrm{C}$ & +++ & + & ++ & - & - \\
\hline & $\mathrm{SY}_{200}$ & +++ & + & ++ & - & - \\
\hline & $\mathrm{SY}_{1,000}$ & + & +++ & ++ & - & - \\
\hline & $\mathrm{SY}_{2,000}$ & + & +++ & ++ & - & - \\
\hline \multirow{4}{*}{$21^{\mathrm{st}}$} & $\mathrm{C}$ & $58.83 \pm 2.68^{\mathrm{b}}$ & $1.67 \pm 0.21^{\mathrm{a}}$ & $37.83 \pm 2.74^{b}$ & $1.00 \pm 0.26^{\mathrm{b}}$ & $0.50 \pm 0.22$ \\
\hline & $\mathrm{SY}_{200}$ & $54.00 \pm 3.22^{b}$ & $17.67 \pm 1.28^{b}$ & $26.50 \pm 2.72^{b}$ & $0.67 \pm 0.33^{\mathrm{ab}}$ & $1.66 \pm 0.33$ \\
\hline & $\mathrm{SY}_{1,000}$ & $24.00 \pm 1.61^{\mathrm{a}}$ & $43.00 \pm 3.62^{\mathrm{c}}$ & $30.50 \pm 2.06^{\mathrm{b}}$ & $0.20 \pm 0.21^{\mathrm{a}}$ & $0.83 \pm 0.40$ \\
\hline & $\mathrm{SY}_{2,000}$ & $27.17 \pm 4.30^{\mathrm{a}}$ & $47.33 \pm 4.89^{c}$ & $24.50 \pm 5.23^{\mathrm{a}}$ & $0.17 \pm 0.16^{\mathrm{a}}$ & $0.83 \pm 0.40$ \\
\hline
\end{tabular}

a,b,c: Values within a column with no common superscripts are significantly $(\mathrm{P}<0.05)$ different. + a few; ++ moderate; +++ mostly; - not seen
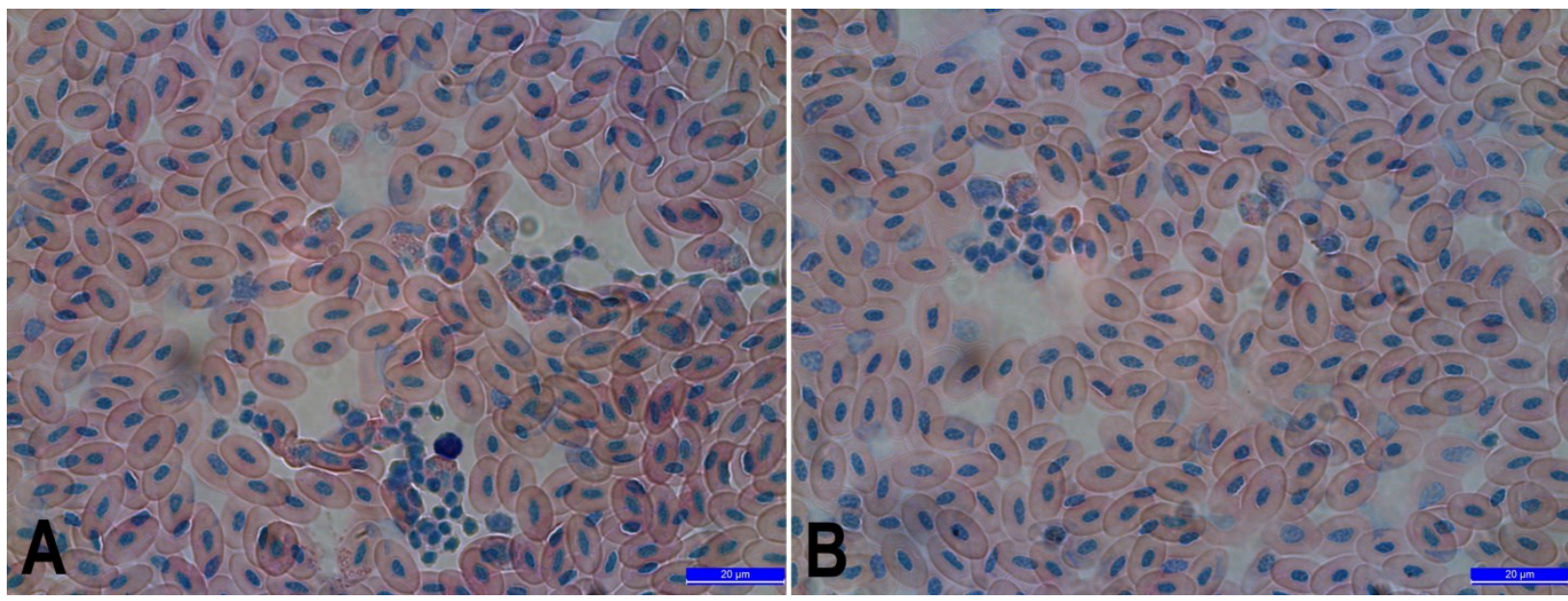

Fig. 2. Light microscopic images of peripheral blood smears on the $21^{\text {st }}$ day of incubation. Eosinophils, heterophils, and lymphocytes were seen in the peripheral blood smear from chick embryos treated with $\mathrm{SY}_{2,000}(\mathrm{~A})$ and $\mathrm{SY}_{1,000}(\mathrm{~B})$

The microscopic evaluation of the thymus sections is presented in Fig. 3. The thymus sections of the control group had normal histological structure. On the $10^{\text {th }}$ day of incubation, there were mostly mesenchymal cell communities. Large basophilic cells that are the precursors of small type lymphocytes were also detected in these areas. In the experimental groups, thymus development was suppressed to an extent dependent on the dose. The most significant changes were observed in the $\mathrm{SY}_{1,000}$ and $\mathrm{SY}_{2,000}$ groups. Cells that were small-type lymphocyte structures were not seen in these groups, while they were in the $\mathrm{SY}_{200}$ group. On day 13 of incubation, the lobule structure in the thymus drafts was prominent in the control group. In these lobules, dark and light stained areas were found. These areas were the cortex, which was rich in small-type lymphocytes, and the medulla, which was poor in these cells. A distinction between the cortex and medulla could be made in this incubation period. Vascularisation was observed to be advanced. When compared to the control group at this time, it was noted that the lobule structure of the thymus was less distinct and the vacuolation was weak in the $\mathrm{SY}_{1,000}$ and $\mathrm{SY}_{2,000}$ groups. The number of small-type lymphocytes also decreased with increasing doses. Cortex-medulla distinction could not be made in these groups. When incubation had taken place for 16 days, the cortex-medulla distinction was more evident in the thymus lobules of the control group. The cortex was dense in small-type lymphocytes. Large blood vessels were seen in the interlobular connective tissue. The most notable change in the $\mathrm{SY}_{1,000}$ and $\mathrm{SY}_{2,000}$ groups was pronounced developmental retardation, seen in small lobule structure, uncertain cortex-medulla separation, poor vascularisation, and undeveloped interlobular connective tissue. On the $21^{\text {st }}$ day, it was determined that the thymus of the control group had completed its development. The capsule surrounding the organ, developed interlobular connective tissue, a prominent cortex-medulla border, developed vascularisation, dense lymphocytes accumulation in the cortex, and Hassall's corpuscles were found. When compared to the control group, the developmental retardation of the thymus was apparent proportional to the doses in the treatment groups. Developmental retardation was most clearly observed in the $\mathrm{SY}_{1,000}$ and $\mathrm{SY}_{2,000}$ groups.

The microscopic evaluation of the bursa of Fabricius sections is given in Fig. 4. Microscopically, bursa of Fabricius of the control group had normal histological structure. On day 10 of incubation, organ drafts with a large lumen were found in the control group. Epithelial evaginations called plica, were seen in these organ drafts. There were also epithelial buds 
formed by large basophilic cell infiltration under the epithelial layer. The haematopoietic areas were in the mesenchymal tissue. It was found that the organ's development was more suppressed in the treatment groups in a dose-dependent manner. The most prominent changes were in the $\mathrm{SY}_{1,000}$ and $\mathrm{SY}_{2,000}$ groups. The number of large basophilic cells under the epithelium was lower in these groups than in the control and $\mathrm{SY}_{200}$ groups. Mesenchymal tissue development was rather weak. It was also observed that plicas and epithelial budding were not formed yet. On the $13^{\text {th }}$ day of incubation, developed plica structures and epithelial buds, a large central lumen, and a few lymphocytes were observed in the organ drafts of the control group. Epithelial budding had advanced in the $\mathrm{SY}_{200}$ group when compared to the $10^{\text {th }}$ day. There were haematopoietic cell foci in the mesenchymal tissue. In the $\mathrm{SY}_{1,000}$ group, there were small epithelial buddings and haematopoietic areas. In the $\mathrm{SY}_{2,000}$ group, large haematopoietic areas, plica development, large basophilic cell infiltration under the epithelial layer, and eosinophil cells began to appear at this time. On the $16^{\text {th }}$ day of the incubation, the fibromuscular layer surrounding the organ was highly developed in the control group. The structures that had completed the epithelial budding stage and/or continued to develop as lymph follicles were seen. It was noted that the medulla of these follicles became prominent and the lymphocyte count increased in this region.

The FAE covering the follicles and the IFE between the two follicles were also prominent. Lymph follicle development was highly suppressed, especially in the $\mathrm{SY}_{1,000}$ and $\mathrm{SY}_{2,000}$ groups. Small lymph follicle drafts were observed in the $\mathrm{SY}_{200}$ group while developing epithelial buds were found in the $\mathrm{SY}_{1,000}$ and $\mathrm{SY}_{2,000}$ groups. In addition, there were haematopoietic areas and eosinophilic cell infiltrations in mesenchymal tissue. The development of FAE and IFE was only visible in the $\mathrm{SY}_{200}$ group. At the end of incubation, there were lamina propria filled with lymph follicles, advanced FAE and IFE, a marked corticomedullar border and cortex region, intense lymphocyte accumulation in the medulla, and interfollicular connective tissue (trabeculae) in the sections of the control group. It was noted that follicular development gradually decreased. Also, there was less lymphocyte accumulation and intense eosinophilic cell infiltrations with increasing doses in the treatment groups. Moreover, we observed that the developments of FAE, IFE, and lymph follicles were significantly suppressed in the $\mathrm{SY}_{2,000}$ group when compared to the control group.
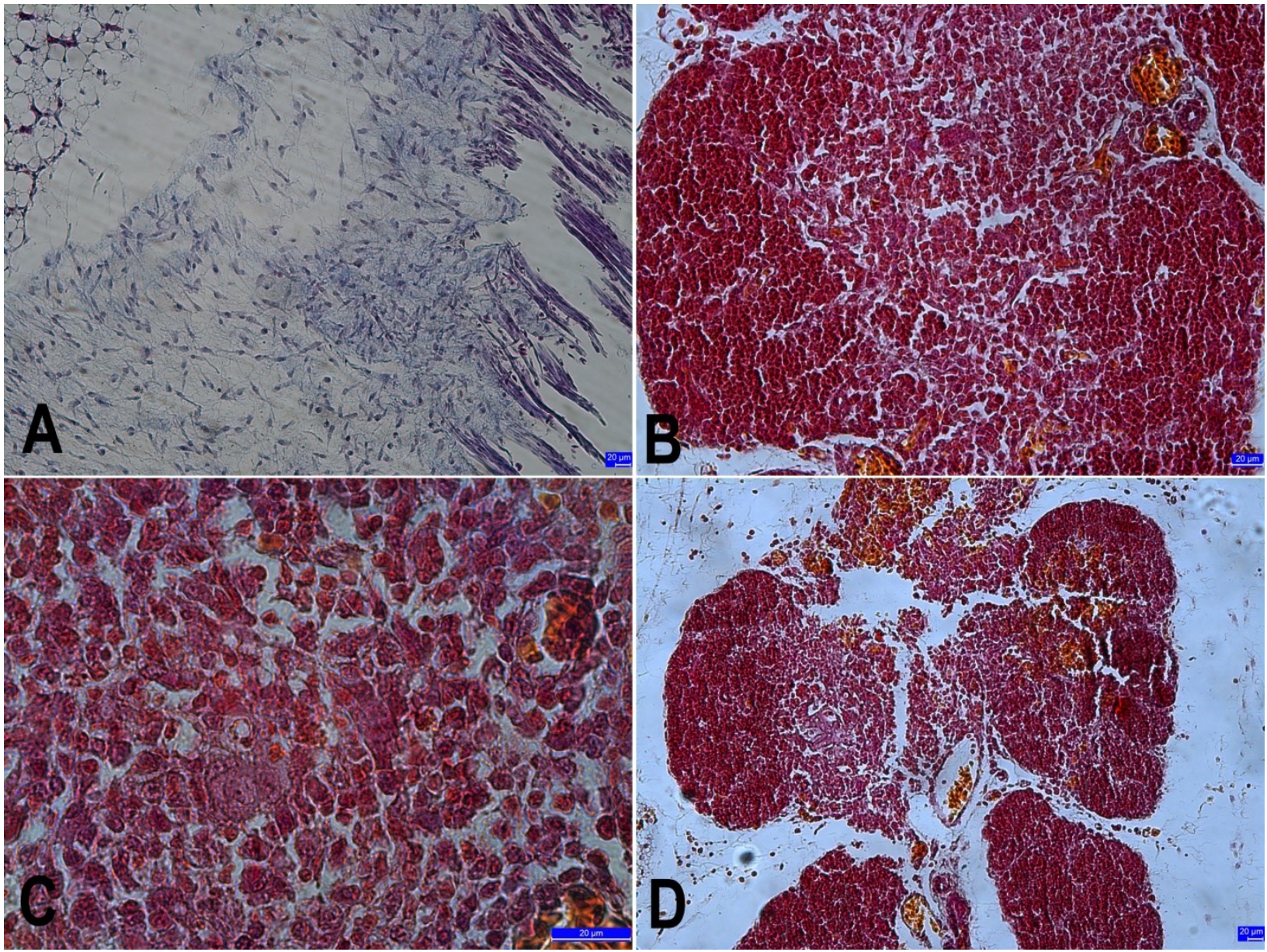

Fig. 3. Light microscopic images of the thymus sections in different embryonic periods. A - the thymus section from a day 10 chick embryo in the control group; $\mathrm{B}$ - the thymus section from a day 21 chick embryo treated with $\mathrm{SY}_{200} ; \mathrm{C}$ - the thymus section from a day 21 chick embryo treated with $\mathrm{SY}_{1,000}$ showing Hassall's corpuscles; D - the thymus section from a day 21 chick embryo treated with $\mathrm{SY}_{2,000}$ 

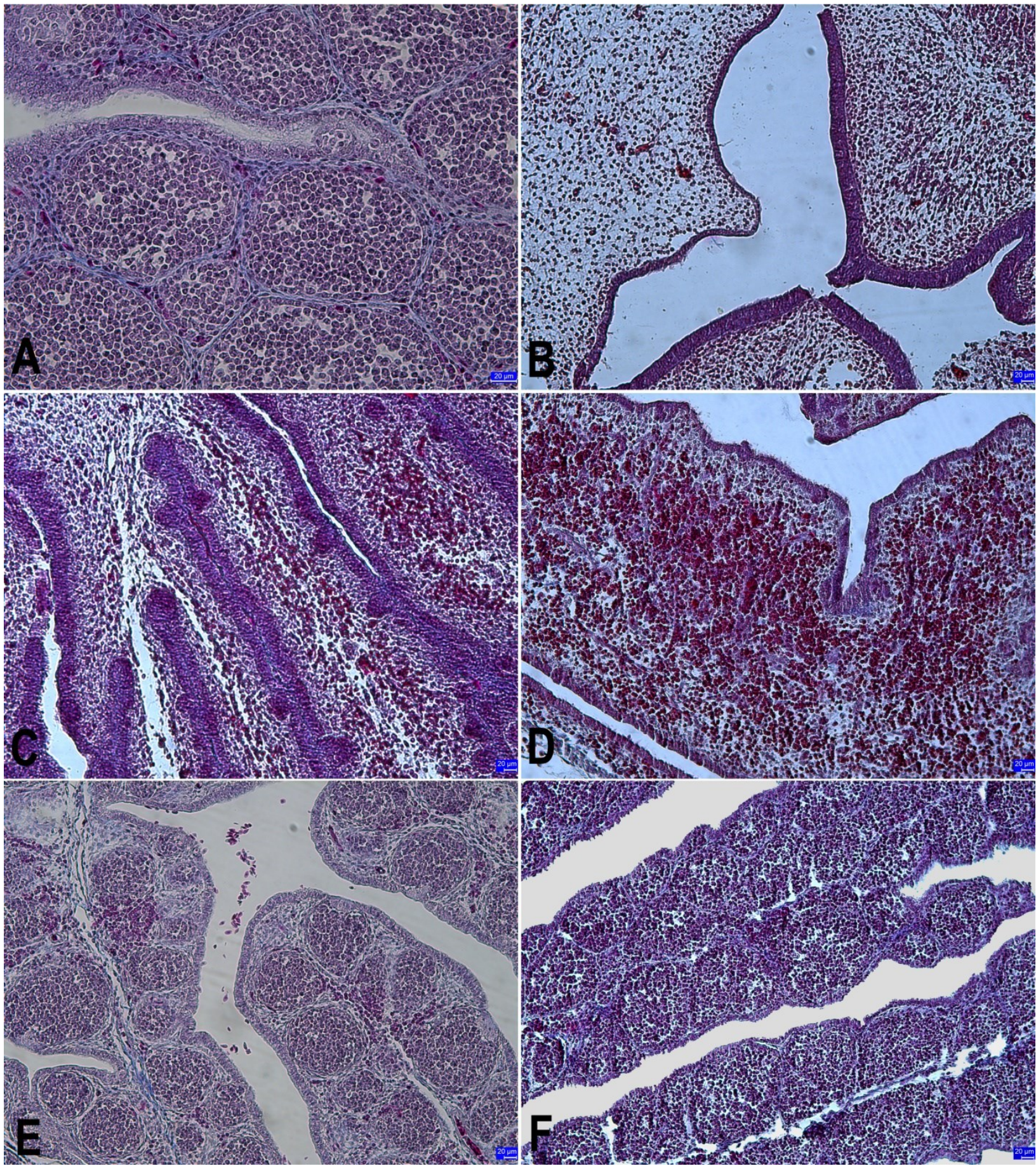

Fig. 4. The bursa of Fabricius sections in different embryonic periods. A - the bursa of Fabricius section from a day 21 chick embryo in the control group showing FAE and IFE; $\mathrm{B}$ - the bursa of Fabricius section from a day 10 chick embryo treated with $\mathrm{SY}_{200}$; $\mathrm{C}$ - the bursa of Fabricius section from a day 13 chick embryo treated with $\mathrm{SY}_{1,000}$ showing epithelial buddings; $\mathrm{D}$ - the bursa of Fabricius section from a day 13 chick embryo treated with $\mathrm{SY}_{2,000} ; \mathrm{E}$ - normal histological image of bursa of Fabricius section from a day 16 chick embryo in the control group; $\mathrm{F}$ - the bursa of Fabricius section from a day 21 chick embryo treated with $\mathrm{SY}_{2,000}$

The microscopic evaluation of the spleen sections is given in Fig. 5. Microscopically, the spleen of the control group had normal histological structure. Spleen sections of the control group consisted of regular reticulum cell accumulation and haematopoietic areas on the $10^{\text {th }}$ day of incubation. The outline of the organ was surrounded by very thin connective tissue. In the SY groups, these cells were dispersed and there was an unclear capsule surrounding the organ draft. On the $13^{\text {th }}$ day of incubation, there were lymphocyte accumulation around the vessels and developing vascularisation. It was observed that spleen-specific follicle development had begun in the parenchyma. The spleen capsule was easily distinguishable. These groups showed weaker vascularization and a thinner capsule than the control group proportional to the dose. In the 
$\mathrm{SY}_{1,000}$ and $\mathrm{SY}_{2,000}$ groups, a few lymphocyte accumulations were found in the tunica adventitia layers of the arteries. Furthermore, there was dense eosinophil cell accumulation in the parenchyma. On the $16^{\text {th }}$ day of incubation, the embryo spleen was surrounded by a developing capsule. Smooth muscle cells could be observed clearly in the capsule. No trabecular structure could be observed yet extending from capsule to parenchyma. Advanced vascularisation was also seen in the tissue: besides the arteria centralis, the arteria and vena trabecularis were found in the parenchyma. It was determined that periarteriolar lymphoid tissue (PAL) formation had started to develop with lymphocyte accumulations around the arteria centralis. Periellipsoidal lymphoid tissue (PEL) formations, which are lymphoid accumulation around ellipsoid capillaries, were developing in white pulp areas. The presence of venous sinuses showed that the red pulp was also developing vessels. White and red pulp could be easily separated. Spleen development was highly suppressed in the treatment groups when compared to the control group. The most significant changes were observed in the $\mathrm{SY}_{1,000}$ and $\mathrm{SY}_{2,000}$ groups. These changes were poorly delineated white and red pulp areas, dilated venous sinuses, mononuclear cell infiltration, small lymphocyte accumulations around the arteria centralis, and eosinophilic cells in the parenchyma. The embryonic development of the spleen was completed on the $21^{\text {st }}$ day of incubation. The spleen capsule consisting of fibrous connective tissue had enlarged significantly from its proportions on the $16^{\text {th }}$ day. The smooth muscle cells in the capsule were easily visible and denser. The vascularisation was more advanced than on day 16 and connective tissue from the capsule to the splenic parenchyma contained an undeveloped trabecular structure as well as trabecular vessels. The arteria linealis and vena linealis were found in the connective tissue outside the capsule. The greatest change in the splenic parenchyma was that the red and white pulp areas could be easily distinguished. PEL formation around the ellipsoid capillaries along with the dense lymphocyte-containing PAL regions around the central artery was clearly seen in the white pulp. The ellipsoid structures in the parenchyma could be observed easily. In addition, subcapsular lymphoid tissue (SCL) formed by lymphocyte accumulations under the capsule and perivenous lymphoid tissue (PVL) were also found around the vena. In the spleen sections of the $21^{\text {st }}$ day chicks, different developmental disorders were determined in the SY groups. White and red pulp areas could be seen in the $\mathrm{SY}_{200}$ group while the distinction of these areas was difficult in the $\mathrm{SY}_{1,000}$ and $\mathrm{SY}_{2,000}$ groups.

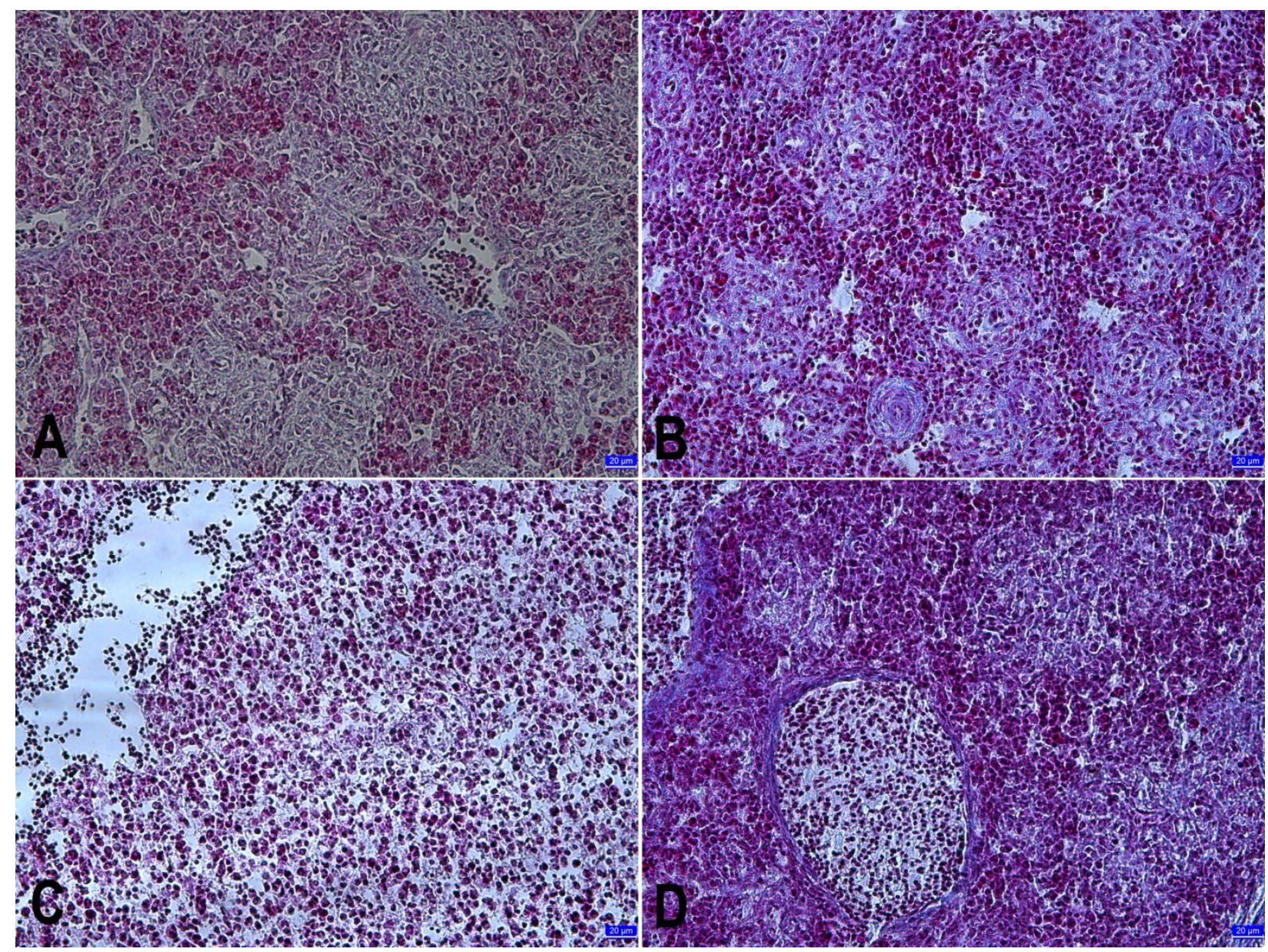

Fig. 5. The spleen sections in different embryonic periods. A - normal histological image of a spleen section from a day 16 chick embryo in the control group; B - the spleen section from a day 21 chick embryo treated with $\mathrm{SY}_{200}$; C - the spleen section from a day 16 chick embryo treated with $\mathrm{SY}_{1,000}$ showing mononuclear cell infiltration; D - the spleen section from a day 21 chick embryo treated with $\mathrm{SY} \mathrm{z}_{2,000}$ 
In addition, small lymphoid formations were observed around the vessels. However, these lymphoid formations were not as developed as those in the control group. Another noticeable change was the presence of intense eosinophilic cell infiltration in parenchyma. As is manifest in the histomorphometric measurements in Table 1, the spleen capsule thickness was statistically significantly different in the control group on the $10^{\text {th }}$ day. The capsule thickness of the $21^{\text {st }}$ day sections was the lowest in the $\mathrm{SY}_{1,000}$ and $\mathrm{SY}_{2,000}$ groups $(\mathrm{P}<0.05)$, while the $\mathrm{SY}_{200}$ group was similar to the control group. On the $13^{\text {th }}$ and $16^{\text {th }}$ days, there was no statistical difference in spleen thickness $(\mathrm{P}>0.05)$.

The measurements of the structures in the bursa of Fabricius are given in Table 1. Lower FAE thickness was found in all SY groups throughout the whole incubation when compared to the control group, and these groups were statistically similar $(\mathrm{P}<0.05)$. On the $10^{\text {th }}$ and $13^{\text {th }}$ days, the lowest IFE thickness was in the $\mathrm{SY}_{1,000}$ and $\mathrm{SY}_{2,000}$ groups $(\mathrm{P}<0.05)$. Furthermore, although the $\mathrm{SY}_{200}$ group was statistically similar to the control group, all SY groups had lower values than that of the control group during the whole incubation $(\mathrm{P}<0.05)$.

\section{Discussion}

Synthetic colours are man-made compounds that are not found in nature. These compounds, containing one or more azo groups, lead to many health problems $(12,13)$. One of the synthetic dyes is SY, which has cytotoxic and genotoxic effects. Although SY has undesirable effects, it is widely used in many industries (20). Many studies have shown that SY has mutagenic and carcinogenic effects $(12,15)$. Moreover, this food dye is found in $15 \%$ of drugs such as antiinflammatories, antihistamines, vitamin medications, bronchodilators, and others. It is stated that preparations containing these compounds may have undesirable effects attributable to the azo compounds in them (3). In 2008, the European Parliament and the Council of the European Union decided that foods and beverages containing some artificial colourings must be labelled with the text "may have unwanted effects on attention and activity in children". Also, according to an EFSA Scientific Opinion, newly submitted data provides a basis to revise the established temporary ADI (12).

The most important elements in the body's defence mechanism are innate and acquired immunity. Cellular and humoral immunity in the organism is achieved by blood cells that are made by primary and secondary lymphoid organs (48). While the thymus and bursa of Fabricius are primary lymphoid organs, the spleen plays an important role in poultry as the largest secondary lymphoid organ. $\mathrm{T}$ and $\mathrm{B}$ lymphocytes in the thymus and bursa of Fabricius respectively settle in the spleen (4). These cells have an effective position in cellular and humoral defence against many pathogenic factors throughout the life of the organism. For the survival of the organism, it is important that these organs complete their development and reach a certain maturity level in order to perform their functions (34).

Jelinek (22) reported that different doses must be tested to determine the embryotoxicity of a substance. It is suggested that administered amounts between the last ineffective dose and the first effective dose are to be tried by the researcher. In order to see the embryotoxic effects of substances such as food additives, pesticides, and drugs, injections should be preferred in early embryonic periods (23).

The number of eggs used for each dose group is highly important in terms of the reliability of the obtained results from embryotoxicity studies. Some researchers have suggested that at least 20 eggs should be used for each group for the reliability of the results $(26,38)$. In this study, 40 eggs were used for each group.

The quality of the numerical measurements made by stereological studies and the accuracy of the sampling plan can be observed by calculating the CE. It is reported that $10 \%$ or less of the $\mathrm{CE}$ in volume calculations made with the Cavalieri principle is an important parameter in terms of the reliability of the study (46). In this study, this value was calculated for the spleen and found to be reliable.

In a study by Hashem et al. (19) to investigate the effect of oral administration of SY on immunological responses, the authors stated that SY has a suppressive effect on cellular immune response rather than humoral. The immunotoxic properties of SY were also investigated by Yadav et al. (50), and it was reported to have such effects. In this study, the obtained results indicated that SY caused significant histopathological changes in the immune system and its organs. These changes are brought about by the compound's possible cytotoxic activity (13). In comparison with the control group, the observed effects were clear on the tissue sections and correlated to dose and embryonic period in the treatment groups.

The thymus is a lymphoepithelial organ originating from epithelial reticular cells and mesenchyme. The epithelial cords formed by the epithelial reticular cells form the lobule structure of the thymus. T lymphocyte precursors, migrating lymphoblasts from the bone marrow on the $7^{\text {th }}-8^{\text {th }}, 12^{\text {th }}-14^{\text {th }}$ and $18^{\text {th }}-20^{\text {th }}$ days of incubation, are produced and cultivated in the thymus as T-lymphocytes and these cells are responsible for cellular immunity (30). Some epithelial reticular cells are also arranged around a centre in order to form Hassall's corpuscles. These are the structures formed by epithelial reticular cell arrangement in tightly-packed concentric layers $(14,42)$. Hassall's corpuscles are important in terms of the antigenic properties of lymphocytes and the elimination of dead lymphocytes formed during T-lymphocyte formation. It is suggested that a thymus which lacks these structures cannot function normally. In the thymic medulla, Hassall's corpuscles can be various sizes, numbers, and acidophilic structures. When studies on the thymus are examined, it is reported that the most important 
degenerative changes in the thymus are necrosis in the central part, cellular depressions, intensive calcification, cystic formations, and macrophages in these structures $(14,30,42)$. It was reported by Hashem et al. (19) that oral administration of SY significantly decreased the weight of the thymus gland of rats. In the microscopic evaluation undertaken in this study, embryonic development of the control group's thymuses was similar to its development observed by other researchers $(4,48)$. In all embryonic periods, the thymuses of the treatment groups showed developmental retardations depending in their extent on the given doses. The most pronounced deficits were observed in the $\mathrm{SY}_{1,000}$ and $\mathrm{SY}_{2,000}$ groups. These results show that SY may cause significant disturbances to both organ development and the cellular defence system of animals.

The bursa of Fabricius, the primary lymphoid organ in poultry, is responsible for the production of B-lymphocytes and immunoglobulin isotype switching. It is the equivalent of bone marrow in mammals $(10,25)$. The removal of this organ, the organ which is responsible for humoral immune response, prevents the formation of regular immune responses against diseases, resulting in poultry deaths. On the $7^{\text {th }}$ day of incubation, B-lymphocyte precursors migrated to the epithelial bursa draft which began to develop on the $4^{\text {th }}-5^{\text {th }}$ days of incubation $(4,7,16)$. Folds, called plica, are formed on the mucosal surface on the $9^{\text {th }}$ day of embryogenesis (7). On the $10^{\text {th }}$ day of incubation, lymph follicle development begins with the arrival of large basophilic cells on the basal surface of the epithelium. As embryonic development progresses, proliferating basophilic cells form buds protruding from epithelium to lumen (39). In the bursa of Fabricius, two types of epithelium were seen, FAE and IFE. In the FAE, pseudostratified columnar epithelium covers the lumenfacing surfaces of developing follicles. In the IFE, a single layer of prismatic epithelium covers the interfollicular regions (11). The development of the lymph follicle is completed in the organ by the $17^{\text {th }}$ day of incubation. Each lymph follicle has a narrow cortex and a large medulla. The cortex and medulla are separated from each other by a corticomedullar border which is the continuation of the IFE (35). The embryonic development of the bursa of Fabricius in the control group was consistent with its development as observed by previous researchers $(4,28)$. The organ development of the $\mathrm{SY}_{1,000}$ and $\mathrm{SY}_{2,000}$ groups was found to be suppressed. Small lymph follicles with low lymphocyte density were detected. According to the measurement results, FAE and IFE thicknesses were significantly lower in all the SY groups than in the control group. The most significant decrease was seen in the $\mathrm{SY}_{1,000}$ and $\mathrm{SY}_{2,000}$ groups. On the $21^{\text {st }}$ day, the FAE thickness was $21.925 \pm 2.488 \mu \mathrm{m}$ in the control group, while this value was $12.920 \pm 0.836 \mu \mathrm{m}$ in the $\mathrm{SY}_{2,000}$ group. On the $10^{\text {th }}$ day, the IFE thickness was $17.642 \pm 1.106 \mu \mathrm{m}$ and $13.862 \pm 0.878 \mu \mathrm{m}$ in the control and $\mathrm{SY}_{2,000}$ groups, respectively. These results suggest that SY may cause significant insufficiencies in both organ development and the humoral immune system.

The spleen is known as the largest vertebrate peripheral lymphoid organ. It has many functions, such as haematopoiesis, controlling the amount of blood cells, creating regular immune responses, and blood filtration and storage. $\mathrm{T}$ and $\mathrm{B}$ lymphocytes, which are immunocompetent cells, settle in the spleen $(1,2,48)$. This organ varies in its characteristics by species, genetics, and age, being ellipsoid, triangular, and globular in the ostrich, duck, and chicken, respectively $(8,48)$. It reaches maximum size 10 weeks after hatching $(27,31)$. The characteristics noted in this study were consistent with other researchers' observations $(8,48)$ for the globular shape of the chick embryonic spleen and its location between the proventriculus and the posterior of the vena cava inferioris. Absolute spleen weight is highly important in assessing the health of animals. In our study, it was observed that absolute spleen weight and size varied according to advancing embryonic periods and health status of embryos. On the $13^{\text {th }}, 16^{\text {th }}$, and $21^{\text {st }}$ days of incubation, the spleen weights of the treatment groups were significantly lower when compared to the control group $(\mathrm{P}<0.05)$. Although there was no statistical difference, spleen weights of the $\mathrm{SY}_{2,000}$ group were higher than those of the $\mathrm{SY}_{200}$ group on days 16 and 21 of incubation $(\mathrm{P}>0.05)$. An increase in spleen weight has been reported to be associated with leukocytosis, erythrophagocytosis, extramedullary haematopoiesis or septic shock (40). The spleen, which does not have a real trabecular structure, is surrounded by a thin capsule $(6,27)$. In this study, the thinnest capsule was determined in the $\mathrm{SY}_{1,000}$ and $\mathrm{SY}_{2,000}$ groups on the $10^{\text {th }}$ and $21^{\text {st }}$ days $(\mathrm{P}<0.05)$. On the $13^{\text {th }}$ and $16^{\text {th }}$ days of incubation, there was no statistical difference, but the lowest thickness was in the $\mathrm{SY}_{2,000}$ group at 7.587 $\pm 0.639 \mu \mathrm{m}$ and $12.424 \pm 0.822 \mu \mathrm{m}$, respectively. Embryonic spleen development begins with the accumulation of mesenchymal cells, and on the $5^{\text {th }}$ day of incubation continues with the formation of sinusoids in this tissue $(31,36)$. Histologically, splenic parenchyma is observed in two different areas as white and red pulp. While white pulp contains periarteriolar deposition of dense and well-organised lymphocytes, red pulp has sinusoidal cavities, blood vessels, splenic cords, and reticular cells (2). Sur and Çelik (49) observed that white pulp development started on the $13^{\text {th }}$ day of incubation. It was reported by Hashem et al. (19) that oral administration of SY did not affect body weight gain or spleen weight. In the microscopic evaluation of this study, embryonic development of the control group spleens was similar to how it was noted by previous researchers $(8,49)$. In all embryonic periods, the spleens of all SY groups showed developmental retardations depending on the given doses. The most significant changes were observed in the $\mathrm{SY}_{1,000}$ and $\mathrm{SY}_{2,000}$ groups. These results, like those indicating SY as harmful to the thymus and bursa of Fabricius, show that SY may cause significant disturbances to spleen functions. 
It was reported that oral administration of SY did not affect total leukocyte count. Moreover, the authors observed that SY caused a significant decrease in circulating mononuclear cell number in peripheral blood and delayed hypersensitivity (19). Eosinophil granulocytes, being non-specific destructive and cytotoxic cells, play an important role in cell-mediated immunity such as in atopic/allergic reactions, response to helminthic parasitic infections and malignancies, and mechanistically in drug side effects and endocrinopathies $(32,47)$. These cells are capable of specifically regulating both innate and adaptive immunity. According to studies, these cells have always been seen as very complex structures (21). One of the health problems attributable to the azo food colouring SY is allergic reactions (41). Güler and Başımoğlu (18) reported that SY $(2.5 \mathrm{mg} / \mathrm{kg})$ injected into the vitellus caused degranulation in dermal and intestinal mast cells. In the present study, eosinophil cell infiltration was seen in the thymus, bursa of Fabricius and spleen tissues of all SY groups. On the $13^{\text {th }}, 16^{\text {th }}$ and $21^{\text {st }}$ days, the $S Y_{1,000}$ and $\mathrm{SY}_{2,000}$ groups had higher eosinophil ratios than the control group in the microscopic evaluation of peripheral blood samples. This result shows that this synthetic dye may engender an immunotoxic effect by causing allergic reactions.

According to the results obtained from the present study, it was concluded that SY used as colouring in many industries has unfavourable effects on the embryonic development of the thymus, bursa of Fabricius, spleen, and blood tissue proportional to the given dose. The ADI of SY was established as $2 \mathrm{mg} / \mathrm{kg}$ by JECFA in 2011. However, we believe that the reliability of this daily consumption limit should be reassessed in the light of this study. The dose given to the eggs in the $\mathrm{SY}_{1,000}$ group was $2 \mathrm{mg} / \mathrm{kg}$. In addition to spurring debate about the ADI for SY, this study offers a model in chick embryos to see the embryological effects in humans. It may be concluded that the use of products containing SY during pregnancy carries great risks for the health of both mother and foetus.

Conflicts of Interests Statement: The authors declare that there is no conflict of interests regarding the publication of this article.

Financial Disclosure Statement: The source of funding of research and the article was the authors' own funds.

Animal Rights Statement: Ethical approval was obtained from Karamanoğlu Mehmetbey University Faculty of Health Sciences Research Ethics Committee (protocol number 2019/29).

\section{References}

1. Aka E., Eren Ü.: Kuluçka Sonrası ilk iki haftada lipopolisakkarit uygulanan ve uygulanmayan broyler civcivlerde dalağın histolojik gelişimi. Erciyes Üniv Vet Fak Derg 2019, 16, 8-15, doi: 10.32707/ercivet.538030

2. Al-Zahaby A.S., Salem M.L., Abdul-Aziz K.K., Serageldeen H.M.: Comparative experimental studies on the spleen of young and aged Balb/C and Cd-1 mice. Int J Adv Res Biol Sci 2017, 4, 226-241, doi: 10.22192/ijarbs.2017.04.12.024.

3. Balbani A.P., Stelzer L.B., Montovani J.C.: Pharmaceutical excipients and the information on drug labels. Braz J Otorhinolaryngol 2006, 72, 400-406, doi: 10.1016/s18088694(15)30976-9.

4. Berktay E.A., Çelik İ.: Sunset yellow FCF'nin (E110), tavukların timus ve bursa Fabricii'sinin embriyonik gelişimi üzerindeki etkisinin histolojik ve enzim histokimyasal yöntemlerle belirlenmesi. PhD thesis, Selcuk University Institute of Health Sciences, Konya, 2014

5. Bhattacharjee M.: Evaluation of mitodepressive effect of Sunset yellow using Allium sativum assay. Int J Sci Environ Technol 2014, 3, 1120-1130.

6. Bingöl S.A., Yecan Gülmez N., Deprem T., Koral Taşcı S., Aslan S.: Histologic and histometric examination of spleen in geese (Anser anser). Atatürk University J Vet 2014, 9, 157-162, doi: 10.17094/avbd.56463.

7. Casteleyn C., Doom M., Lambrechts E., Van Den Broeck W., Simoens P., Cornillie P.: Locations of gut-associated lymphoid tissue in the 3-month-old chicken: a review. Avian Pathol 2010, 39, 143-150, doi: 10.1080/03079451003786105.

8. Cesta M.F.: Normal structure, function, and histology of the spleen. Toxicol Pathol 2006, 34, 455-465, doi: 10.1080/01926230600867743.

9. Çolakoğlu F., Selçuk M.L.: Morphohistological evaluation of embryonic development of bursa Fabricius in chicks. F U Vet $\mathrm{J}$ Health Sci 2020, 34, 35-39.

10. Çolakoğlu F., Dönmez H.H.: Kanatlıların sindirim kanalı lenfoid dokusu. Atatürk Üniv Vet Bil Derg 2018, 13, 106-111, doi: 10.17094/ataunivbd.417626.

11. Davenport Jr W.D., Allen E.R.: Dome epithelium and follicleassociated basal lamina pores in the avian bursa of Fabricius. Anat Rec 1995, 241, 155-162, doi: 10.1002/ar.1092410203.

12. EFSA (European Food Safety Authority): Reconsideration of the temporary ADI and refined exposure assessment for Sunset Yellow FCF (E110). EFSA J 2014, 12, 3765, doi: 10. 2903/j. efsa. 2014.3765.

13. Elbanna K., Sarhan O.M., Khider M., Elmogy M., Abulreesh H.H., Shaaban M.R.: Microbiological, histological, and biochemical evidence for the adverse effects of food azo dyes on rats. J FDA 2017, 25, 667-680, doi: 10.1016/j.jfda.2017.01.005.

14. Erdem E., Dabak D.Ö., Ozan İ.E.: Timusa özgü hassal cisimcikleri. Firat Tip Dergisi 2017, 22, 60-66.

15. Feng J., Cerniglia C.E., Chen H.: Toxicological significance of azo dye metabolism by human intestinal microbiota. Front Biosci 2012, 4, 568-586.

16. Funk P.E., Palmer J.L.: Dynamic control of B lymphocyte development in the bursa of Fabricius. Arch Immunol Ther Exp 2003, 51, 389-398.

17. Gundersen H.J., Jensen E.B., Kieu K., Nielsen J.: The efficiency of systematic sampling in stereology reconsidered. J Microscop 1999, 193, 199-211, doi: 10.1046/j.1365-2818.1999.00457.x.

18. Güler T., Başımoğlu K.Y.: Sunset yellowun tavuk embriyosu deri ve barsak mast hücrelerinde degranülasyon etkileri. Kafkas Univ Vet Fak Derg 2013, 19, 851-856, doi: 10.9775/kvfd.2013.8982.

19. Hashem M.M., Atta A.H., Arbid M.S., Nada S.A., Asaad G.F.: Immunological studies on Amaranth, Sunset Yellow and Curcumin as food colouring agents in albino rats. Food Chem Toxicol 2010, 48, 1581-1586, doi: 10.1016/j.fct.2010.03.028.

20. Ismail M.A., Sakr S.M.: Validation of replacement of the synthetic food dye sunset yellow-induced hepatotoxicity and genotoxicity with the nutraceutical curcumin in mice. Merit Res J Med Med Sci 2016, 4, 25-50.

21. Jacobsen E.A., Helmers R.A., Lee J.J., Lee N.A.: The expanding role(s) of eosinophils in health and disease. Blood 2012, 120, 3882-3890, doi: 10.1182/blood-2012-06-330845. 
22. Jelinek R.: The chick embryotoxicity screening test (CHEST). In: Methods in Prenatal Toxicology, edited by D. Neubert, H.J. Merker, T.E. Kwasigrooh, Georg Thieme, Stuttgart, 1977, pp. 381-386.

23. Jelinek R., Peterka M., Rychter Z.: Chick embryotoxicity screening test-130 substances tested. Indian J Exp Biol 1985, 23, 588-595.

24. Joint FAO/WHO Expert Committee on Food Additives: Compendium of food additive specifications, $74^{\text {th }}$ Meeting, Food and Agriculture Organization of the United Nations (FAO), Roma, 2011. http://www.fao.org/docrep/01 4/i2358e/i2358e00.pdf.

25. Karadag Sari E., Altunay H., Kurtdede N., Bakır B.: The structure of bursa of Fabricius in the long-legged buzzard (Buteo rufinus): Histological and histochemical study. Acta Vet (Beogr) 2015, 65, 510-517, doi: 10.1515/acve-2015-0043.

26. Kemper F.H., Luepke N.P.: Toxicity testing by the hen's egg test (HET). Food Chem Toxicol 1986, 24, 647-648.

27. Khenenou T., Berghiche A., Rahmoun D.E., Berberis A.: Morpho-histological study of the spleen of broiler chickens during post-haching age. Int J Vet Sci Anim Husb 2018, 3, 22-23.

28. Kocaöz N., Çelik İ., Ünsal S.: Kuluçkadan Çıkıştan Sonra Tavuk Bursa Fabricii'sinde Oluşan Histolojik Değişiklikler. Vet Bil Derg 1997, 13, 43-51.

29. Konuk T.: Kan Dokusu Preparatları Boyama Yöntemleri. In: Pratik Fizyoloji, edited by T. Konuk, AÜ Vet Fak Yayınevi, Ankara, 1981, p. 276.

30. Kumar B.V., Connors T.J., Farber D.L.: Human T cell development, localization, and function throughout life. Immunity 2018, 48, 202-213, doi: 10.1016/j.immuni.2018.01.007.

31. Liman N., Bayram G.K.: Structure of the quail (Coturnix coturnix japonica) spleen during pre- and post-hatching periods. Rev Med Vet 2011, 162, 25-33.

32. Lu C.H., Hsieh C.H.: Elevation of creatine kinase during medical treatment of Grave's disease. Med Sci 2007, 27, 241-244.

33. Mayhew T., Gundersen H.: If you assume, you can make an ass out of $u$ and me: a decade of the disector for stereological counting of particles in 3D space. J Anat 1996, 188, 1-15.

34. Nicholson L.B.: The immune system. Essays Biochem 2016, 60, 275-301, doi: 10.1042/ebc20160017.

35. Olah I., Glick B.: Follicle-associated epithelium and medullary epithelial tissue of the bursa of Fabricius are two different compartments. Anat Rec 1992, 233, 577-587, doi: 10.1002/ar.1092330412.

36. Olah I., Vervelde L.: Structure of the Avian Lymphoid System. In: Avian Immunology, edited by F. Davison, B. Kaspers, K. Schat, Elsevier Academic Press, London, 2008, pp. 13-50.

37. Olsen R., Kudirkiene E., Thøfner I., Pors S., Karlskov-Mortensen P., Li L.: Impact of egg disinfection of hatching eggs on the eggshell microbiome and bacterial load. Poult Sci 2017, 96, 3901-3911, doi: 10.3382/ps/pex182.

38. Prelusky D.B., Hamilton R.M., Foster B.C., Trenholm H.L., Thompson B.K.: Optimization of chick embryotoxicity bioassay for testing toxicity potential of fungal metabolites. J AOAC 1987, 70, 1049-1055.

39. Ratcliffe M.J.H.: The ontogeny and cloning of B cells in the bursa of Fabricius. Immunol Today 1985, 6, 223-227, doi: 10.1016/0167-5699(85)90039-8.

40. Resendez J.C., Rehagen D.: Infusion Toxicology and Techniques. In: A Comprehensive Guide to Toxicology in Preclinical Drug Development, edited by A.S. Faqi, Academic Press, Elsevier, Waltham, 2013, pp. 277-307.

41. Reza M.S.A., Hasan M.M., Kamruzzaman M., Hossain M.I., Zubair M.A., Bari L.: Study of a common azo food dye in mice model: Toxicity reports and its relation to carcinogenicity. Food Sci Nutr 2019, 7, 667-677, doi: 10.1002/fsn3.906.

42. Ross M.H., Pawlina W.: Lymphatic System. In: Histology A Text and Atlas, edited by M.H. Ross, W. Pawlina, Lippincott Williams \& Wilkins, Baltimore, 2011, pp. 440-441.

43. Schneider C.A., Rasband W.S., Eliceiri K.W.: NIH Image to Image J: 25 years of image analysis. Nature Methods 2012, 9, 671-675, doi: 10.1038/nmeth.2089.

44. Selçuk M.L., Bahar S.: The morphometric properties of the lumbar spinal cord segments in horses. J Anim Vet Adv 2014, 13, 653-659, doi: 10.3923/javaa.2014.653.659.

45. Selçuk M.L., Çolakoğlu F.: Distinction of gray and white matter for some histological staining methods in New Zealand rabbit's brain. Int J Cur Res Rev 2020, 12, 11-17, doi: 10.31782/IJCRR.2020.12112.

46. Selçuk M.L., Tıpırdamaz S.: A morphological and stereological study on brain, cerebral hemispheres and cerebellum of New Zealand rabbits. Anat Histol Embryol 2020, 49, 90-96, doi: 10.1111/ahe. 12489 .

47. Shamri R., Xenakis J.J., Spencer L.A.: Eosinophils in innate immunity: an evolving story. Cell Tissue Res 2011, 343, 57-83, doi: 10.1007/s00441-010-1049-6.

48. Song H., Peng K., Li S., Wang Y., Wei L., Tang L.: Morphological characterization of the immune organs in ostrich chicks. Turk J Vet Anim Sci 2012, 36, 89-100, doi: 10.3906/vet0910-128.

49. Sur E., Çelik İ.: Yumurtaya verilen aflatoksin B1'in tavuk dalağının embriyonik gelişimi üzerindeki etkileri: histolojik bulgular. Vet Bil Derg 2004, 20, 103-110.

50. Yadav A., Kumar A., Tripathi A., Das M.: Sunset yellow FCF, a permitted food dye, alters functional responses of splenocytes at non-cytotoxic dose. Toxicol Lett 2013, 217, 197-204. 